\title{
molecules
}

ISSN 1420-3049

http://www.mdpi.org

Full Paper

\section{A Simple Synthesis of 2-Thiohydantoins ${ }^{\dagger}$}

\author{
Zerong Daniel Wang *, Samia O. Sheikh and Yulu Zhang \\ Department of Chemistry, University of Houston-Clear Lake, 2700 Bay Area Boulevard, Houston, TX \\ 77058, U.S.A., Tel: +1-281-283-3795, Fax: +1-281-283-3709 \\ ${ }^{\dagger}$ Dedicated to the memory of Professor Ramiro Sánchez
}

* Author to whom correspondence should be addressed; E-mail: wang@uhcl.edu

Received: 9 August 2006; in revised form: 24 August 2006 / Accepted: 24 August 2006 / Published: 2 October 2006

\begin{abstract}
Thiohydantoin derivatives are produced by heating a mixture of thiourea and an $\alpha$-amino acid. The method described offers the advantages of simplicity, low cost, easy work-up and scalability.
\end{abstract}

Keywords: Amino acids, Antiviral agents, Cyclization, Heterocycles, 2-Thiohydantoin

\section{Introduction}

Thiohydantoins are sulfur analogs of hydantoins with one or both carbonyl groups replaced by thiocarbonyl groups [1]. Among the known thiohydantoins, 2-thiohydantoins are most notably known due of their wide applications as hypolipidemic [2], anticarcinogenic [3], antimutagenic [4], antithyroidal [5] antiviral (e.g., against herpes simplex virus, HSV) [6], human immunodeficiency virus (HIV) [7] and tuberculosis [8]), antimicrobial (antifungal and antibacterial) [9], anti-ulcer and anti-inflammatory agents [10], as well as pesticides [11]. Additionally, 2-thiohydantoins have been used as reference standards for the development of C-terminal protein sequencing [12], as reagents for the development of dyes [13] and in textile printing, metal cation complexation and polymerization catalysis [14]. It is therefore not surprising that various different synthetic methods have been developed to prepare 2-thiohydantoin and its derivatives. Some of the most commonly used methods are the treatment of $\alpha$-amino acids with acetic anhydride followed by ammonium thiocyanate [15] and the coupling reaction between $\alpha$-amino acid derivatives and isothiocyanate [4a,12b,16]. Other preparative methods for 2-thiohydantoins include the reactions between thiourea and benzil [17], 
thiourea and $\alpha$-halo acids [18], oxazolinone and thiocyanate [19], amino amide and diimidazole thiocarbonate [20], and others [21]. In addition, some of the above reactions have been modified to take place under microwave irradiation [17c] and solid-phase [16a,22] or fluorous-phase [23] supported reaction conditions. However, the above methods often suffer from one or more synthetic limitations for large-scale preparation of 2-thiohydantoin derivatives due to their use of expensive, moisture sensitive and/or highly toxic starting materials and reagents. Moreover, the methods developed for combinatorial synthesis and used to prepare 2-thiohydantoin derivatives in small quantities for purposes like biological testing may not be feasible when operated on a large scale [22d,24]. We now report a simple method for the preparation of 2-thiohydantoin derivatives that can easily be scaled up in the laboratory.

\section{Results and Discussion}

This reaction, giving moderate to high yields of 2-thiohydantoins, involves the direct condensation between $\alpha$-amino acids and thiourea, as generally depicted in Scheme 1. In detail, a mixture of thiourea and an $L$ - $\alpha$-amino acid are allowed to react directly in the absence of any solvent at temperatures ranging from 170 to $220^{\circ} \mathrm{C}$. This novel reaction has been carried out under four different conditions: the reactions are carried out in a flask under reflux using i), a heating mantle or ii), an oil bath as the heat source, iii) in a sealed stainless reactor equipped with magnetic stirring and heated by an oil bath, and iv), in a Parr acid digestion bomb placed in a preheated furnace maintained at a constant temperature. The various reaction results are listed in Table 1.

Scheme 1. The general preparation of 2-thiohydantoins from $\alpha$-amino acids and thiourea.
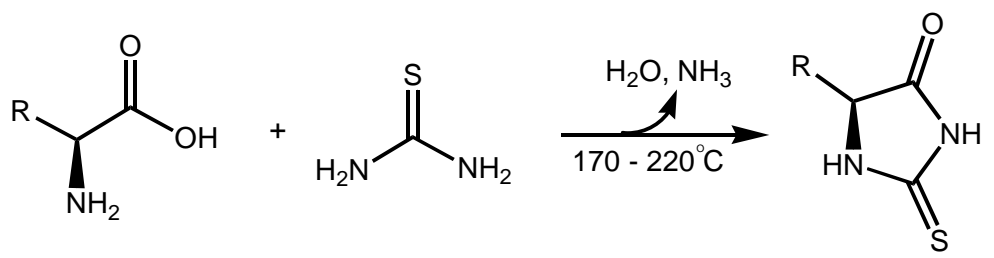

As shown in Table 1, of the four sets of reaction conditions studied, the one involving refluxing the liquified mixtures of amino acid and thiourea in an oil-bath gave the best yields, ranging from $79 \%$ to almost $100 \%$. These yields vary as a function of the structure of the amino acid used. In contrast, refluxing the same mixtures in a heating mantle generally gives much lower yields (from 23 to $78 \%$ ). On the other hand, whereas heating the reactants in a Parr acid digestion bomb in a temperaturecontrolled furnace does not apparently improve the yields, compared to heating the same reagents via a heating mantle, the use of a sealed magnetically stirred stainless reactor heated by an oil bath gives yields almost comparable to the reactions performed via oil bath heating (although the former technique has other technical issues, discussed below). The differences in yields noted under the various experimental conditions described herein are readily attributable to the respective mixing efficacies and the duration of heating. For instance, the generally lower yields resulting from the reaction conditions involving refluxing in a heating mantle can be attributed to the "hot spots" arising from uneven heating that cause decomposition of the starting materials or resultant products. Likewise, although the reactions performed in the temperature-controlled furnace suffer from relatively minimal temperature variations, due to the good control of the heating source, there is still the limitation of the 
absence of even mixing and the observed lower yields in this case were probably due to the lack of stirring in the furnace. In addition, even though the $\alpha$-amino acid to thiourea ratio (which ranged from 1:1 to $1: 3$ ) has almost no effect on the final yields of 2-thiohydantoins in the tested reactions, the yield enhancement observed with shorter cooking periods has led us to set our optimized reaction conditions, namely refluxing the reagent mixture in an oil bath for no more than half an hour.

Table 1. The yields of 2-thiohydantoins under various conditions ${ }^{\mathrm{a}}$.

\begin{tabular}{|c|c|c|c|c|c|}
\hline Condition & Amino Acid (g) & Ratio & Temp. $\left({ }^{\circ} \mathrm{C}\right)^{\mathbf{b}}$ & Time (min) & Yield (\%) \\
\hline \multirow[t]{12}{*}{ Oil bath } & Ile (2.038) & $1: 3$ & $180-195$ & 30 & 96 \\
\hline & Ala (2.042) & $1: 3$ & $180-195$ & 30 & 92 \\
\hline & Val (2.032) & $1: 3$ & $180-195$ & 30 & 93 \\
\hline & Leu (2.022) & $1: 3$ & $180-195$ & 30 & 94 \\
\hline & Gly (2.042) & $1: 3$ & $180-195$ & 30 & 91 \\
\hline & Phe (5.008) & $1: 3$ & $180-195$ & 30 & 93 \\
\hline & Pro (2.109) & $1: 3$ & $180-195$ & 30 & 92 \\
\hline & Cys (2.126) & $1: 3$ & $180-195$ & 30 & $79^{\mathrm{c}}$ \\
\hline & Met (2.006) & $1: 3$ & $180-195$ & 30 & 89 \\
\hline & Tyr (2.074) & $1: 3$ & $180-195$ & 30 & 88 \\
\hline & $\operatorname{Trp}(2.061)$ & $1: 3$ & $180-195$ & 30 & 87 \\
\hline & Thr (2.045) & $1: 3$ & $180-195$ & 30 & 85 \\
\hline \multirow[t]{14}{*}{ Furnace } & Ile (1.012) & $1: 2$ & 190 & 60 & 75 \\
\hline & Ala (0.514) & $1: 2$ & 190 & 120 & 20 \\
\hline & Val (1.005) & $1: 2$ & 183 & 60 & 26 \\
\hline & Leu (0.501) & $1: 2$ & 180 & 60 & 30 \\
\hline & Gly (0.501) & $1: 2$ & 190 & 60 & 55 \\
\hline & Phe (0.531) & $1: 2$ & 180 & 60 & 52 \\
\hline & Pro (0.534) & $1: 2$ & 175 & 120 & 58 \\
\hline & Cys (1.002) & $1: 2$ & 180 & 120 & $47^{\mathrm{c}}$ \\
\hline & Met (0.513) & $1: 2$ & 190 & 120 & 31 \\
\hline & Thr (0.503) & $1: 2$ & 190 & 120 & 24 \\
\hline & Asp (1.001) & $1: 2$ & 180 & 60 & $\sim^{\mathrm{d}}$ \\
\hline & Asn (1.048) & $1: 2$ & 180 & 60 & $\sim^{\mathrm{d}}$ \\
\hline & His (1.120) & $1: 2$ & 180 & 120 & $\sim^{\mathrm{d}}$ \\
\hline & Glu (0.504) & $1: 2$ & 180 & 120 & $\sim^{\mathrm{d}}$ \\
\hline \multirow[t]{3}{*}{ Heating Mantle } & Ile (1.013) & $1: 2$ & 190 & 60 & 60 \\
\hline & Ala (1.001) & $1: 2$ & 185 & 60 & 36 \\
\hline & Val (1.003) & $1: 2$ & $195-215$ & 60 & 36 \\
\hline
\end{tabular}


Table 1. Cont.

\begin{tabular}{llllcc}
\hline Condition & Amino Acid (g) & Ratio & Temp. $\left({ }^{\circ} \mathbf{C}\right)^{\mathbf{b}}$ & Time (min) & Yield (\%) \\
\hline Heating Mantle & Leu (1.003) & $1: 2$ & $200-210$ & 60 & 39 \\
& Gly (1.016) & $1: 2$ & $170-200$ & 60 & 36 \\
& Phe (1.002) & $1: 2$ & $210-220$ & 60 & 78 \\
& Pro (1.001) & $1: 2$ & $180-205$ & 60 & 23 \\
& Cys (1.022) & $1: 2$ & $170-200$ & 60 & $28^{\mathrm{c}}$ \\
& Met (1.007) & $1: 2$ & $185-200$ & 60 & 41 \\
& Tyr (1.002) & $1: 2$ & $180-200$ & 60 & 48 \\
& Trp (1.012) & $1: 2$ & $200-205$ & 60 & 57 \\
& Thr (1.004) & $1: 2$ & $187-220$ & 60 & 45 \\
& Asp (1.001) & $1: 2$ & $175-220$ & 60 & $\sim^{\mathrm{d}}$ \\
& Asn (1.001) & $1: 2$ & $175-205$ & 60 & $^{\mathrm{d}}$ \\
& His (1.003) & $1: 2$ & $195-200$ & 60 & $\sim^{\mathrm{d}}$ \\
\hline
\end{tabular}

a Only one reaction was carried out in the sealed stainless reactor, see Experimental section for details; ${ }^{\mathrm{b}}$ Thermometer was not calibrated; ${ }^{\mathrm{c}}$ The corresponding desulfurized product, i.e., (S)-5methyl-2-thiohydantoin was obtained, the same product as obtained from alanine; ${ }^{\mathrm{d}}$ The corresponding 2-thiohydantoins are not obtained.

After the reactions, the products can be purified by silica gel column chromatography. More importantly, those 2-thiohydantoins resulting from amino acids with non-polar side chains can be isolated simply by precipitation from water, as any thiourea left in the reaction mixtures is very watersoluble. From the reactions and conditions tested during the course of this study, it was observed that all the amino acids with non-polar side chains such as glycine, alanine, valine, leucine, isoleucine, proline, phenylalanine, and methionine readily react with thiourea to form the corresponding 2-thiohydantoins. In addition, some other amino acids with polar side chains such as tryptophan and tyrosine also react with thiourea to give the corresponding 2-thiohydantoins. It was surprising to note that the reaction between $L$-cysteine and thiourea yields 5-methyl-2-thiohydantoin, the same product obtained from the reaction between $L$-alanine and thiourea. The formation of such an unexpected product could be attributed to thermal desulfurization. In contrast, the corresponding 2-thiohydantoins arising from other natural amino acids, such as histidine, aspartic acid, asparagine, glutamic acid, glutamine, lysine and arginine were not obtained or isolated under our reaction conditions. In parallel, it has been repeatedly reported that the traditional Johnson treatment of $\alpha$-amino acids with acetic anhydride and ammonium thiocyanate in acetic acid also failed to yield the corresponding 2thiohydantoins derived from aspartate [25], lysine [26], glutamine [26], glutamate [26], arginine [26], as well as proline [12b,25]. We rationalize such failures in our case to the fact that amino acids such as arginine, asparate, asparagine, glutamate, glutamine and lysine are known to decompose at temperatures close to our reaction temperatures [27] and are therefore unstable under the reaction conditions; in addition, some amino acids like glutamic acid, glutamine, aspartic acid or asparagine may conceivably undergo side reactions involving their second functional groups, that might attack the thiohydantoin rings formed. Nevertheless, we hope that the failure to prepare 2-thiohydantoins derived 
from glutamic acid, arginine etc. by the proposed method will not detract from the potential and value of this reaction for Medicinal Chemistry, as it has been reported that 2-thiohydantions with non-polar substituents at C-5 display effective biological activities, whereas those with polar groups at that position are not effective [5a].

Moreover, it has been observed that under the oil bath heating conditions, the reaction yields increase as the reaction scale increases. For example, a 96\% yield of 5-sec-butyl-2-thiohydantoin was obtained from 2 grams of $L$-isoleucine and thiourea (Table 1 ), and an almost quantitative yield was obtained when $6.0 \mathrm{~g}$ of $L$-isoleucine were heated with thiourea, whereas our initial trial of this reaction using $0.5 \mathrm{~g}$ of $L$-isoleucine only yielded $78 \%$ of the (S)-5-sec-butyl-2-thiohydantoin product. The yield enhancement on a larger reaction scale is attributed to the proportionally lower product losses during the work-up process. Accordingly, it is possible that this reaction holds a great deal of potential of scalability for larger quantity production to satisfy the need of medicinal and pharmaceutical applications.

All the 2-thiohydantoins formed were characterized through UV, MS and NMR spectral analyses. A characteristic UV absorbance was observed in the 260-270 nm range for the 2-thiohydantoins prepared in this study (Table 2), which is consistent with the reported absorption of $270 \mathrm{~nm}$ for these species [16d]. The MS spectra were recorded using an ESI APPI detector under both positive and negative ionization modes, and results are also summarized in Table 2. In general, all 2-thiohydantoins showed three characteristic ${ }^{1} \mathrm{H}-\mathrm{NMR}$ chemical shifts at 4.0-4.5 ppm (H-5), 8.9-9.5 ppm (H at N-1) and 10.5-11.0 ppm ( $\mathrm{H}$ at $\mathrm{N}-3$ ), that correspond to the thiohydantoin ring protons. Furthermore, 2-thiohydantoins also show characteristic peaks in their ${ }^{13} \mathrm{C}-\mathrm{NMR}$ spectra: at 50-70 ppm for C-5 and 156187 ppm for either thiocarbonyl or carbonyl groups (Table 3).

Table 2. The UV-Vis and MS data of prepared 2-thiohydantoins ${ }^{\mathrm{a}}$.

\begin{tabular}{|c|c|c|c|}
\hline \multirow[t]{2}{*}{ 2-Thiohydantoin } & \multirow{2}{*}{$\begin{array}{c}\lambda_{\max }(\mathrm{nm}) \text { for } \\
\mathrm{UV}-\mathrm{Vis}\end{array}$} & \multicolumn{2}{|c|}{ MS data } \\
\hline & & $\mathrm{M}^{+}$ & $\mathrm{M}^{-}$ \\
\hline Gly-thiohydantoin & 262 & 117 & 115 \\
\hline Ala-thiohydantoin & 263 & 131 & 129 \\
\hline Val-thiohydantoin & 266 & 159 & 157 \\
\hline Leu-thiohydantoin & 265 & 173 & 171 \\
\hline Ile-thiohydantoin & 265 & 173 & 171 \\
\hline Phe-thiohydantoin & 265 & 207 & 205 \\
\hline Pro-thiohydantoin & 268 & 157 & 155 \\
\hline Met-thiohydantoin & 265 & 191 & 189 \\
\hline Tyr-thiohydantoin & 265 & 223 & 221 \\
\hline Trp-thiohydantoin & 264 & $\sim^{\mathrm{b}}$ & 244 \\
\hline
\end{tabular}

It should be pointed out that we have not observed any racemization at the 5-positions of 2-thiohydantoins prepared under our reaction conditions. This was concluded from the analysis of the ${ }^{1} \mathrm{H}$ NMR spectra of the 2-thiohydantoins, by the comparison of representative NMR spectra of $(S)$-5- 
isopropyl-2-thiohydantoin derived from $L$-valine and the mixed $(R)$ - and $(S)$-5-iso-propyl-2thiohydantoin prepared from racemic $D L$-valine under the same conditions, as shown in Figure 1 . In addition, no extra peaks were observed for the NMR of (S)-5-isopropyl-2-thiohydantoin in the presence of a chemical shift reagent, i.e., $\mathrm{Eu}(\mathrm{fod})_{3}$. It is clear that the two methyl groups in enantiomerically pure (S)-thiohydantoin appear as two characteristic doublets in its ${ }^{1} \mathrm{H}$-NMR, whereas the NMR of the racemic mixture shows two pairs of overlapped and duplicated doublets. On the other hand, when we heated pure $L$-valine at a temperature above $220^{\circ} \mathrm{C}$ for one hour, we did observe partial racemization according to the NMR spectra, indicating that our reaction conditions are safe to prepare enantiomerically pure 2-thiohydantions from $L$-amino acids.

Figure 1. A comparison of NMR spectra between (S)-5-isopropyl-2-thiohydantoin and the mixed 5-isopropyl-2-thiohydantoin.
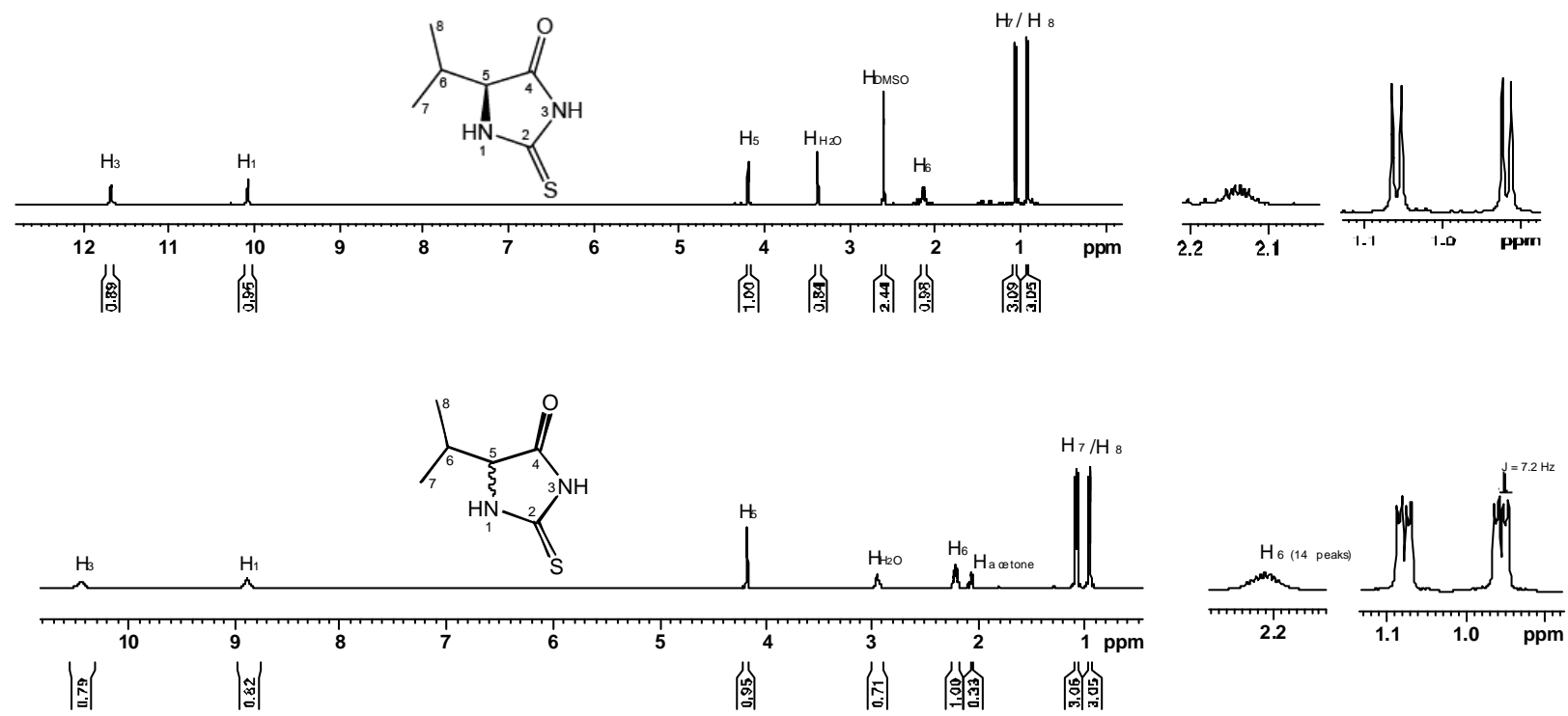

Shown in Scheme 2 is the proposed mechanism for this simple reaction, where one of the two thiourea amino groups attacks an amino acid carboxyl group to form an amide bond with loss of a water molecule. Next, the amino acid $\alpha$-amino group attacks the thiocarbonyl group, accompanied by the evolution of an ammonia molecule. Thus, the amino acid $\alpha$-amino group becomes part of the 2-thiohydantoin moiety and no racemization occurs at the amino acid $\alpha$-position during the cyclization. The proposed mechanism is supported by the result of the reaction between $L$-valine and $N$ allylthiourea, shown in Scheme 3. In this reaction two 2-thiohydantoins are obtained in a 2.3:1 ratio, resulting from the attack of nitrogens of the different amino groups of $N$-allylthiourea on the amino acid carboxyl group. In this particular reaction, the initial attack on the carboxyl group by the $N$-allylthiourea primary amino group and subsequent addition of the $\alpha$-amino group to the thiocarbonyl, followed by the evolution of allyl amine, results in the formation of (S)-5-isopropyl-2-thiohydantoin $\left(R_{f}=0.32\right.$, hexanes-EtOAc $\left.=2: 1\right)$, which is identical to the product produced directly from the reaction with thiourea. In contrast, the initial attack of the allylic secondary amino group following a similar path would yield $(S)-N^{3}$-allyl-5-isopropyl-2-thiohydantoin $\left(R_{f}=0.52\right.$, hexanes-EtOAc $\left.=2: 1\right)$, whose ${ }^{1} \mathrm{H}-\mathrm{NMR}$ spectrum clearly indicates the disappearance of the N-3 proton in the $10.5-11.0 \mathrm{ppm}$ range, as shown in the Experimental section. These two 2-thiohydantoins are readily separated by column chromatography using 2:1 hexane-EtOAc as eluent. It is assumed that the preference for formation of 
(S)- $N^{3}$-allyl-5-isopropyl-2-thiohydantoin is due to the higher basicity and nucleophilicity of the secondary amino group attached to the allyl group, although the allyl group may conceivably increase the steric hindrance for the initial attack from the secondary amino group on the carboxyl group. Clearly, this steric effect does not overcome the effects of nucleophilicity and basicity in controlling the reaction outcome.

Scheme 2. The mechanism of 2-thiohydantoin formation.

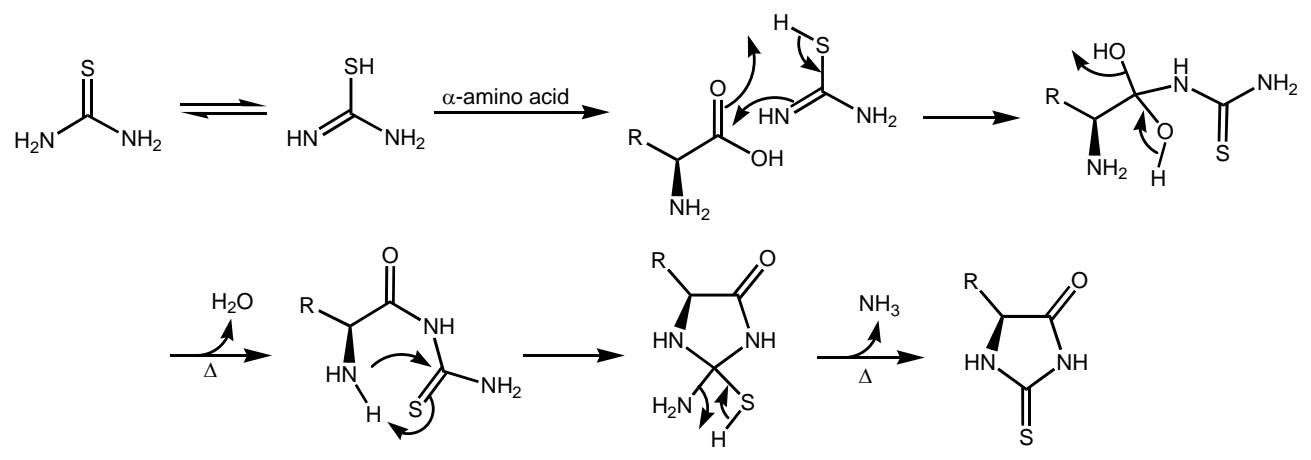

Scheme 3. The reaction between L-valine and N-allylthiourea.

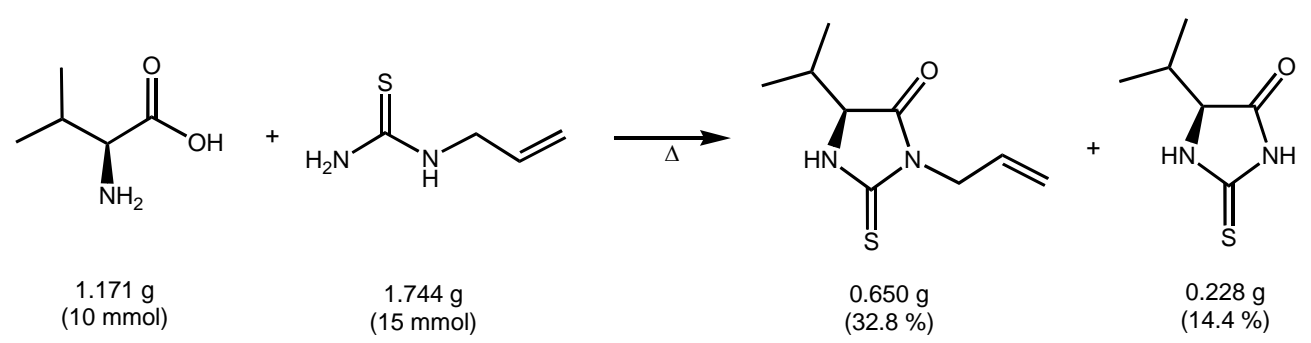

\section{Conclusions}

In summary, we have described a novel synthetic method for the preparation of 2-thiohydantoins from thiourea and $\alpha$-amino acids containing non-polar side chains, which have some advantages over the already known methods. For example, this reaction offers the advantages of an easy work-up process, fast reaction rates, high yields and the use of cheap and less toxic starting materials. In addition, our method can easily convert $L$-proline into its 2-thiohydantoin derivative, whereas the often used Johnson method employing isothiocyanate failed [12b].

\section{Experimental Section}

\section{General}

Enantiomerically pure $(L)$ - $\alpha$-amino acids (except for $(L)$ - $\alpha$-isoleucine, which was a mixture of diastereomers), were purchased from Acros and used without further purification. Thiourea (Acros) was used as received, as were solvents such as ethyl acetate and hexane (VWR International). Precoated silica gel $\mathrm{F}_{254}$ plates (Merck) from Aldrich were used for TLC. Column chromatographies were performed over silica gel using hexane and ethyl acetate as eluents. The purity of the compounds 
prepared in this study is verified by both TLC and ${ }^{1} \mathrm{H}$ and ${ }^{13} \mathrm{C}-\mathrm{NMR}$ spectra (listed at the end of the Experimental section). Both UV and MS spectra are obtained on an Agilent Technologies 1100 series LC/MS machine, using an isocratic water-methanol (1:1) mixture as solvent. MS were recorded using both positive and negative ionization modes. All the NMR spectra $\left({ }^{1} \mathrm{H}-,{ }^{13} \mathrm{C}-, \mathrm{H}-\mathrm{H}\right.$ COSY [28], $\mathrm{H}-\mathrm{C}$ HSQC) were recorded at various temperatures on a Bruker Avance $600 \mathrm{MHz}$ spectrometer located at the University of Houston central campus, using TMS as internal standard and operating at $600 \mathrm{MHz}$ for ${ }^{1} \mathrm{H}$ and $150 \mathrm{MHz}$ for ${ }^{13} \mathrm{C}$, respectively. Acetone- $\mathrm{d}_{6}, \mathrm{CDCl}_{3}$ or DMSO- $\mathrm{d}_{6}$ were used as the solvents for the NMR measurements. The results, reported in ppm on the $\delta$ scale, are summarized in Table 3 . The stainless reactor was assembled at University of Houston-Clear Lake at Dr. R. Sánchez's lab. The high pressure acid digestion bomb (model No. 4746), equipped with a $23 \mathrm{~mL}$ PTFE cup (A255 AC), was purchased from the Parr Instrument Company.

\section{Representative reaction procedure using an oil bath}

A 1:3 mixture of $L$-isoleucine (2.038 g) and thiourea (3.529 g) was placed in a flask and heated under stirring. When the oil bath temperature reached $180^{\circ} \mathrm{C}$, the mixture started to melt (m.p. of thiourea $175-178^{\circ} \mathrm{C}$ [27]) and about 5 minutes later (when the temperature reached $190^{\circ} \mathrm{C}$ ) the homogenous liquid started to fume and reflux and the solution turned an amber color. After 10 minutes, the fuming ceased and after refluxing at this temperature for an additional 15 minutes, the reaction was complete as monitored by TLC. The flask was allowed to cool down and water $(20 \mathrm{~mL})$ was added while the flask was still warm. The solution was reheated to dissolve all the solids and allowed to cool to room temperature, then placed in a refrigerator for 3 hours. The crystals were removed by vacuum filtration, and the mother liquid was extracted with ethyl acetate. The isolated crystals were already pure (S)-5-sec-butyl-2-thiohydantoin, whereas the EtOAc extract was further purified by flash column chromatography. The yields are shown in Table 1 along with the reactions of other amino acids.

\section{Reactions heated by a heating mantle}

The reaction procedure was almost the same as that used for the oil bath conditions, except for the lack of temperature control and the use of a 1:2 amino acid-thiourea ratio. After completion of reaction, the solid mixture was pulverized and loaded directly on a column for chromatography. The results are listed in Table 1.

\section{Reaction in the Paar acid hydrolysis bomb}

A 1:2 ratio of amino acid and thiourea was placed in the PTFE cup and inserted into the acid digestion bomb, which was sealed and place in a furnace preheated to the desired temperature. After 1 to 2 hours, the acid digestion bomb was taken out and left in fume hood to cool down. The resulting brown colored mixture was extracted with EtOAc and purified by column chromatography. The results are shown in Table 1.

Reaction in a metal reactor equipped with magnetic stirring and immersed in an oil bath 
To a $250 \mathrm{~mL}$ stainless reactor, were added a magnetic stir bar, $L$-isoleucine (5.009 g, $38.2 \mathrm{mmol}$ ) and thiourea (5.836 g, $76.8 \mathrm{mmol}$ ). After sealing, the reactor was immersed halfway into an oil bath preheated to $195^{\circ} \mathrm{C}$, and stirred magnetically. At different intervals, the metal reactor was taken out of oil bath and the contents sampled to monitor the completion of reaction by TLC. When the reaction was complete, water was added into the reactor to wash out the resulting product, which was purified in a similar way to that described in the oil bath treatment to afford $5.65 \mathrm{~g}$ of (S)-5-sec-butyl-2thiohydantoin (86\% yield). As it was very difficult and inconvenient to monitor the reaction under these conditions, no further reactions of thiourea with other amino acids were carried out using this setup.

Table 3. NMR data of prepared 2-thiohydantoins.*

\begin{tabular}{|c|c|}
\hline Compound & NMR data \\
\hline Gly-thiohydantoin & $\begin{array}{l}\left.{ }^{1} \mathrm{H}-\mathrm{NMR}\left(\mathrm{DMSO}-\mathrm{d}_{6}, 303 \mathrm{~K}\right): 4.03 \text { (dd, } \mathrm{J}_{1}=14.67, \mathrm{~J}_{2}=6.54 \mathrm{~Hz}, 2 \mathrm{H}, \alpha-\mathrm{H}\right), 9.80(\mathrm{~s}, 1 \mathrm{H} \text {, } \\
\mathrm{NH}), 11.61(\mathrm{~s}, 1 \mathrm{H}, \mathrm{NH}) ;{ }^{13} \mathrm{C}-\mathrm{NMR}\left(\mathrm{DMSO}_{6}, 303 \mathrm{~K}\right): 54.21(\alpha-\mathrm{C}), 178.40,187.38 .\end{array}$ \\
\hline Ala-thiohydantoin & $\begin{array}{l}{ }^{1} \mathrm{H}-\mathrm{NMR}\left(\mathrm{DMSO}-\mathrm{d}_{6}, 303 \mathrm{~K}\right): 1.22(\mathrm{~d}, \mathrm{~J}=6.14 \mathrm{~Hz}, 3 \mathrm{H}, \beta-\mathrm{H} \text { on Me), } 4.01 \text { (q, J=6.15 } \\
\mathrm{Hz}, 1 \mathrm{H}, \alpha-\mathrm{H}), 9.05(\mathrm{~s}, 1 \mathrm{H}, \mathrm{NH}), 10.56(\mathrm{~s}, 1 \mathrm{H}, \mathrm{NH}) ;{ }^{13} \mathrm{C}-\mathrm{NMR}\left(\mathrm{DMSO}-\mathrm{d}_{6}, 303 \mathrm{~K}\right) \text { : } \\
21.75(\beta-\mathrm{C}), 51.19(\alpha-\mathrm{C}), 181.17,186.00 .\end{array}$ \\
\hline Val-thiohydantoin & $\begin{array}{l}\left.{ }^{1} \mathrm{H}-\mathrm{NMR}\left(\mathrm{DMSO}_{\mathrm{f}}, 303 \mathrm{~K}\right): 0.83 \text { (d, J=6.79 Hz, } 3 \mathrm{H}, \mathrm{Me}\right), 0.97(\mathrm{~d}, \mathrm{~J}=6.95 \mathrm{~Hz}, 3 \mathrm{H} \text {, } \\
\text { Me), 2.02-2.08 (m, } 1 \mathrm{H}, \beta-\mathrm{H}), 4.10(\mathrm{~d}, \mathrm{~J}=3.39 \mathrm{~Hz}, 1 \mathrm{H}, \alpha-\mathrm{H}), 9.99(\mathrm{~s}, 1 \mathrm{H}, \mathrm{NH}), 11.60 \\
(\mathrm{~s}, 1 \mathrm{H}, \mathrm{NH}) ;{ }^{13} \mathrm{C}-\mathrm{NMR}\left(\mathrm{DMSO}-\mathrm{d}_{6}, 303 \mathrm{~K}\right): 20.05(\gamma-\mathrm{C}), 22.20(\gamma-\mathrm{C}), 33.93(\beta-\mathrm{C}) \text {, } \\
69.73(\alpha-\mathrm{C}), 179.85,186.91 .\end{array}$ \\
\hline Leu- & $\begin{array}{l}\left.{ }^{1} \mathrm{H}-\mathrm{NMR} \text { (acetone- } \mathrm{d}_{6}, 280 \mathrm{~K}\right): 0.97(\mathrm{~d}, \mathrm{~J}=6.64 \mathrm{~Hz}, 6 \mathrm{H}, 2 \mathrm{Me}), 1.63-1.68(\mathrm{~m}, 2 \mathrm{H}, \beta-\mathrm{H}) \text {, } \\
\left.\text { 1.91-1.98 (m, } 1 \mathrm{H}, \gamma-\mathrm{H}), 4.34 \text { (dd, J } \mathrm{J}_{1}=8.58, \mathrm{~J}_{2}=5.22 \mathrm{~Hz}, 1 \mathrm{H}, \alpha-\mathrm{H}\right), 9.14(\mathrm{~s}, 1 \mathrm{H}, \mathrm{NH}) \text {, } \\
\left.\text { 10.63 (s, } 1 \mathrm{H}, \mathrm{NH}) ;{ }^{13} \mathrm{C}-\mathrm{NMR} \text { (acetone- } \mathrm{d}_{6}, 280 \mathrm{~K}\right): 12.08(\mathrm{Me}), 13.69(\mathrm{Me}), 15.51(\gamma- \\
\text { C), } 31.28(\beta-\mathrm{C}), 50.76(\alpha-\mathrm{C}), 167.23,174.04 .\end{array}$ \\
\hline Ile-1 & $\begin{array}{l}(S, S)-\text { and }(R, S) \text {-diasteromeric mixtures in a ratio of 1.38:1; }{ }^{1} \mathrm{H}-\mathrm{NMR} \text { (acetone- } \mathrm{d}_{6} \text {, } \\
298 \mathrm{~K}): 0.89(\mathrm{~d}, \mathrm{~J}=6.78 \mathrm{~Hz}, \beta-\mathrm{Me}, 1.9 \mathrm{H}), 0.93(\mathrm{t}, \mathrm{J}=7.50 \mathrm{~Hz}, \delta \text {-Me, } 1.1 \mathrm{H}), 0.97(\mathrm{t}, \mathrm{J} \\
=7.38 \mathrm{~Hz}, \delta-\mathrm{Me}, 1.6 \mathrm{H}), 1.04(\mathrm{~d}, \mathrm{~J}=6.96 \mathrm{~Hz}, \beta-\mathrm{Me}, 1.40 \mathrm{H}), 1.30-1.43(\mathrm{~m}, \gamma-\mathrm{H}, 1 \mathrm{H}) \text {, } \\
1.48-1.60(\mathrm{~m}, \gamma-\mathrm{H}, 1 \mathrm{H}), 4.28(\mathrm{~d}, \mathrm{~J}=3.66 \mathrm{~Hz}, \mathrm{H}-5,0.42 \mathrm{H}), 4.34(\mathrm{~d}, \mathrm{~J}=3.18 \mathrm{~Hz}, \mathrm{H}-5 \text {, } \\
0.59 \mathrm{H}), 8.96(\mathrm{~s}, 1 \mathrm{H}, \mathrm{NH}), 10.55(\mathrm{~s}, 1 \mathrm{H}, \mathrm{NH}) ;{ }^{13} \mathrm{C}-\mathrm{NMR}\left(\text { acetone- } \mathrm{d}_{6}, 298 \mathrm{~K}\right): 2.17 \\
(\mathrm{Me}), 2.30(\mathrm{Me}), 3.92(\mathrm{Me}), 5.48(\mathrm{Me}), 14.84(\gamma-\mathrm{C}), 16.78(\gamma-\mathrm{C}), 28.16(\beta-\mathrm{C}), 28.24 \\
(\beta-\mathrm{C}), 55.91(\mathrm{C}-5), 56.75(\mathrm{C}-5), 166.18,166.67,174.29,174.61 .\end{array}$ \\
\hline Met- & $\begin{array}{l}{ }^{1} \mathrm{H}-\mathrm{NMR}\left(\mathrm{DMSO}_{6}, 303 \mathrm{~K}\right): 1.81-1.86(\mathrm{~m}, 1 \mathrm{H}, \beta-\mathrm{H}), 1.93-1.97(\mathrm{~m}, 1 \mathrm{H}, \beta-\mathrm{H}), 2.05 \\
(\mathrm{~d}, \mathrm{~J}=0.82 \mathrm{~Hz}, 3 \mathrm{H}, \mathrm{Me}), 2.54-2.57(\mathrm{~m}, 2 \mathrm{H}, \gamma-\mathrm{H}), 4.30\left(\mathrm{dd}, \mathrm{J}_{1}=6.75, \mathrm{~J}_{2}=6.06 \mathrm{~Hz}, 1 \mathrm{H} \text {, }\right. \\
\alpha-\mathrm{H}) ;{ }^{13} \mathrm{C}-\mathrm{NMR}\left(\mathrm{DMSO}_{6}, \mathrm{~d}_{6}, 303 \mathrm{~K}\right): 18.38(\mathrm{Me}), 32.56(\gamma-\mathrm{C}), 34.21(\beta-\mathrm{C}), 63.45(\alpha- \\
\text { C), } 180.21,186.49 .\end{array}$ \\
\hline Phe-thiohydantoin & $\begin{array}{l}\left.{ }^{1} \mathrm{H}-\mathrm{NMR} \text { (acetone- } \mathrm{d}_{6}, 280 \mathrm{~K}\right): 3.09\left(\mathrm{dd}, \mathrm{J}_{1}=14.20, \mathrm{~J}_{2}=5.92 \mathrm{~Hz}, 1 \mathrm{H}, \beta-\mathrm{H}\right), 3.21\left(\mathrm{dd}, \mathrm{J}_{1}=\right. \\
\left.\text { 14.15, } \mathrm{J}_{2}=4.7 \mathrm{~Hz}, 1 \mathrm{H}, \beta-\mathrm{H}\right), 4.63(\mathrm{t}, \mathrm{J}=4.8 \mathrm{~Hz}, 1 \mathrm{H}, \alpha-\mathrm{H}), 7.24-7.31(\mathrm{~m}, 5 \mathrm{H}, \mathrm{Ph}), 9.10 \\
(\mathrm{~s}, 1 \mathrm{H}, \mathrm{NH}), 10.47(\mathrm{~s}, 1 \mathrm{H}, \mathrm{NH}) ;{ }^{13} \mathrm{C}-\mathrm{NMR}\left(\text { acetone- } \mathrm{d}_{6}, 280 \mathrm{~K}\right): 27.58(\beta-\mathrm{C}), 53.40(\alpha- \\
\text { C), } 118.24(\mathrm{Ph}), 119.59(\mathrm{Ph}), 120.97(\mathrm{Ph}), 126.58(\mathrm{Ph}), 166.12,174.15 .\end{array}$ \\
\hline
\end{tabular}


Table 3. Cont.

\begin{tabular}{|c|c|}
\hline Tyr-thiohydantoin & $\begin{array}{l}\left.{ }^{1} \mathrm{H}-\mathrm{NMR} \text { (acetone- } \mathrm{d}_{6}, 280 \mathrm{~K}\right): 3.26\left(\mathrm{dd}, \mathrm{J}_{1}=14.98, \mathrm{~J}_{2}=6.34 \mathrm{~Hz}, 1 \mathrm{H}, \beta-\mathrm{H}\right), 3.35(\mathrm{dd}, \\
\left.\mathrm{J}_{1}=14.96, \mathrm{~J}_{2}=4.34 \mathrm{~Hz}, 1 \mathrm{H}, \beta-\mathrm{H}\right), 4.63\left(\mathrm{dd}, \mathrm{J}_{1}=4.72, \mathrm{~J}_{2}=1.58 \mathrm{~Hz}, 1 \mathrm{H}, \alpha-\mathrm{H}\right), 7.00-7.033 \\
(\mathrm{~m}, 1 \mathrm{H}, \mathrm{Ph}), 7.07-7.11(\mathrm{~m}, 1 \mathrm{H}, \mathrm{Ph}), 7.38(\mathrm{~d}, \mathrm{~J}=8.06 \mathrm{~Hz}, 1 \mathrm{H}, \mathrm{Ph}), 7.63(\mathrm{~d}, \mathrm{~J}=7.99 \mathrm{~Hz} \text {, } \\
1 \mathrm{H}, \mathrm{Ph}), 9.10(\mathrm{~s}, 1 \mathrm{H}, \mathrm{NH}), 10.23(\mathrm{~s}, 1 \mathrm{H}, \mathrm{OH}), 10.45(\mathrm{~s}, 1 \mathrm{H}, \mathrm{NH}) ;{ }^{13} \mathrm{C}-\mathrm{NMR} \\
\left.\text { (acetone- } \mathrm{d}_{6}, 280 \mathrm{~K}\right): 17.55(\beta-\mathrm{C}), 53.09(\alpha-\mathrm{C}), 109.65(\mathrm{Ph}), 109.93(\mathrm{Ph}), 112.43(\mathrm{Ph}), \\
115.23(\mathrm{Ph}), 166.57,174.09 .\end{array}$ \\
\hline Trp-t & $\begin{array}{l}\left.\left.{ }^{1} \mathrm{H}-\mathrm{NMR} \text { (acetone- } \mathrm{d}_{6}, 280 \mathrm{~K}\right): 2.89 \text { (dd, } \mathrm{J}_{1}=14.47, \mathrm{~J}_{2}=8.93 \mathrm{~Hz}, 1 \mathrm{H}, \mathrm{b}-\mathrm{H}\right), 3.10 \text { (dd, J } \\
\left.=14.50, \mathrm{~J}_{2}=4.61 \mathrm{~Hz}, 1 \mathrm{H}, \mathrm{b}-\mathrm{H}\right), 4.44-4.48(\mathrm{~m}, 1 \mathrm{H}, \alpha-\mathrm{H}), 6.97(\mathrm{t}, \mathrm{J}=7.86 \mathrm{~Hz}, 1 \mathrm{H}), 7.05 \\
(\mathrm{t}, \mathrm{J}=7.14 \mathrm{~Hz}, 1 \mathrm{H}), 7.31(\mathrm{~d}, \mathrm{~J}=8.1 \mathrm{~Hz}, 1 \mathrm{H}), 7.38(\mathrm{~s}, 1 \mathrm{H}, \mathrm{NH}), 7.59(\mathrm{~d}, \mathrm{~J}=7.98 \mathrm{~Hz}, 1 \\
\mathrm{H}), 7.92(\mathrm{~d}, \mathrm{~J}=8.17 \mathrm{~Hz}, 1 \mathrm{H}), 8.93(\mathrm{~s}, 1 \mathrm{H}, \mathrm{NH}), 10.12(\mathrm{~s}, 1 \mathrm{H}, \mathrm{NH}) ;{ }^{13} \mathrm{C}-\mathrm{NMR} \\
\left.\text { (acetone- } \mathrm{d}_{6}, 280 \mathrm{~K}\right): 17.65(\beta-\mathrm{C}), 53.17(\mathrm{C}-5), 99.44,102.42,109.64,110.00,112.49 \text {, } \\
\text { 115.20, 118.75, 127.64, 161.44, 166.59. }\end{array}$ \\
\hline Pro- & $\begin{array}{l}\left.{ }^{1} \mathrm{H}-\mathrm{NMR} \text { (acetone- } \mathrm{d}_{6}, 280 \mathrm{~K}\right): 1.78-1.83(\mathrm{~m}, 1 \mathrm{H}, \beta-\mathrm{H}), 2.19-2.28(\mathrm{~m}, 3 \mathrm{H}, \beta-\mathrm{H}, \gamma-\mathrm{H}, \gamma- \\
\left.\mathrm{H}^{\prime}\right), 3.44\left(\mathrm{ddd}, \mathrm{J}_{1}=11.53, \mathrm{~J}_{2}=8.58, \mathrm{~J}_{3}=3.06 \mathrm{~Hz}, 1 \mathrm{H}, \delta-\mathrm{H}\right), 3.82-3.87(\mathrm{~m}, 1 \mathrm{H}, \delta-\mathrm{H}) \text {, } \\
\left.\text { 4.39 (dd, } \mathrm{J}_{1}=10.14, \mathrm{~J}_{2}=6.56 \mathrm{~Hz}, 1 \mathrm{H}, \alpha-\mathrm{H}\right), 10.42(\mathrm{~s}, 1 \mathrm{H}, \mathrm{NH}) ;{ }^{13} \mathrm{C}-\mathrm{NMR} \text { (acetone- } \mathrm{d}_{6} \text {, } \\
\text { 280K): } 17.41(\beta-\mathrm{C}), 18.01(\gamma-\mathrm{C}), 38.81(\delta-\mathrm{C}), 57.71(\alpha-\mathrm{C}), 165.66,177.32 .\end{array}$ \\
\hline $\begin{array}{l}\mathrm{N}^{3} \text {-allyl-Val-thio- } \\
\text { hydantoin }\end{array}$ & 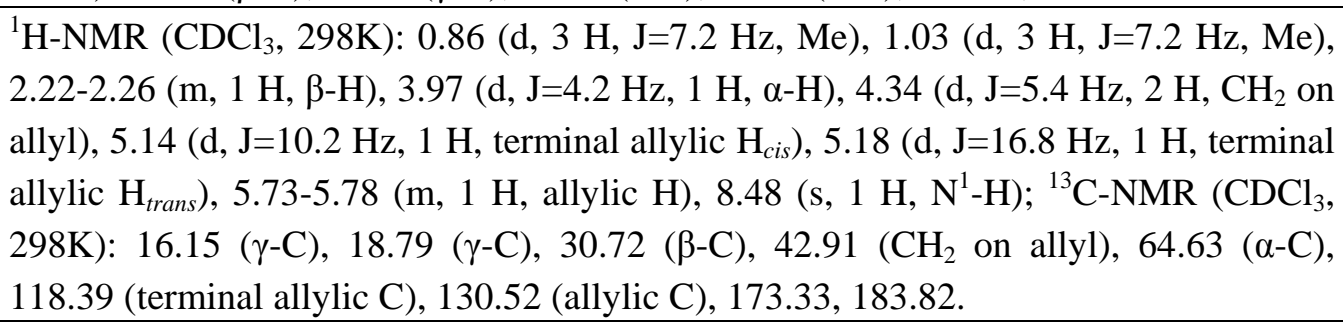 \\
\hline
\end{tabular}

* Representative ${ }^{1} \mathrm{H}$ - and ${ }^{13} \mathrm{C}-\mathrm{NMR}$ spectra are provided as Supplementary Data.

\section{Acknowledgements}

We thank the Robert Welch Foundation for financial support of this research (BC-1586).

\section{References and Notes}

1. Johnson, T. B.; Chernoff, L. H. J. Am. Chem. Soc. 1913, 35, 1208.

2. (a) Tompkins, J. E. J. Med. Chem. 1986, 29, 855; (b) Elwood, J. C.; Richert, D. A.; Westerfeld, W. W. Biochem. Pharmacol. 1972, 21, 1127.

3. Al-Obaid, A. M.; El-Subbagh, H. I.; Khodair, A. I.; Elmazar, M. M. Anticancer Drugs 1996, 7, 873.

4. (a) Takahashi, A.; Matsuoka, H.; Ozawa, Y.; Uda, Y. J. Agric. Food Chem. 1998, 46, 5037; (b) Froelich, E.; Fruehan, A.; Jackman, M.; Kirchner, F. K.; Alexander, E. J.; Archer, S. J. Am. Chem. Soc. 1954, 76, 3099.

5. (a) Marx, J. V.; Richert, D. A.; Westerfeld, W. W. J. Med. Chem. 1970, 13, 1179; (b) Cheymol, J.; Chabrier, P.; Gay, Y.; Lavedan, J. P. Arch. Int. Pharmacodyn. Ther. 1951, 88, 342; (c) Cheymol, J.; Chabrier, P.; Gay, Y. Arch. Int. Pharmacodyn. Ther. 1951, 87, 321.

6. El-Barbary, A. A.; Khodair, A. I.; Pedersen, E. B.; Nielsen, C. J. Med. Chem. 1994, 37, 73.

7. (a) Chérouvrier, J.-R.; Carreaux, F.; Bazureau, J. P. Molecules, 2004, 9, 867, and references cited therein; (b) Khodair, A. I.; El-Subbagh, H. I.; El-Emam, A. A. Boll. Chim. Farm. 1997, 136, 561. 
8. Archer, S.; Unser, M. J.; Froelich, E. J. Am. Chem. Soc. 1956, 78, 6182.

9. (a) Lacroix, G.; Bascou, J.-P.; Perez, J.; Gadras, A. U. S. Pat. 6,018,052, 2000; (b) Lacroix, G.; Bascou, J.-P.; Perez, J.; Gadras, A. U. S. Pat. 5,650,519, 1997; (c) Marton, J.; Enisz, J.; Hosztafi, S.; Timar, T. J. Agric. Food Chem. 1993, 41, 148.

10. Curran, A. C. W. U. S. Pat. 3,984,430, 1976.

11. Nagpal, K. L. U. S. Pat. 4,473,393, 1984.

12. (a) Mo, B.; Li, J.; Liang, S. Anal. Biochem. 1997, 249, 207; (b) Cromwellt, L. D.; Stark, G. R. Biochemistry 1969, 8, 4735.

13. (a) Nelson, J. V.; Helber, M. J.; Brick, M. C. U. S. Pat. 5,695,917, 1997; (b) Ooi, T.; Fukui, T.; Kobayashi, M.; Ueno, K.; Kagami, K.; Suzuki, M.; Nishino, K. U. S. Pat. 5,482,814, 1996.

14. Kandil, S. S.; El-Hefnawy, G. B.; Baker, E. A. Thermochim. Acta 2004, 414, 105.

15. (a) Wyzlic, I. M.; Tjarks, W.; Soloway, A. H.; Perkins, D. J.; Burgos, M.; O’Reilly, K. P. Inorg. Chem. 1996, 35, 4541; (b) Johnson, T. B.; Bengis, R. J. Am. Chem. Soc. 1913, 35, 1605; (c) Johnson, T. B.; Nicolet, B. H. J. Am. Chem. Soc. 1912, 34, 1973; (d) Johnson, T. B.; Scott, W. M. J. Am. Chem. Soc. 1913, 35, 1130.

16. (a) Li, J.-P.; Ma, C.-M.; Qu, G.-R. Synth. Commun. 2005, 35, 1203; (b) Innocenti, A.; Casini, A.; Alcaro, M. C.; Papini, A. M.; Scozzafava, A.; Supuran, C. T. J. Med. Chem. 2004, 47, 5224; (c) Elokdah, H.; Sulkowsk, T. S.; Abou-Gharbia, M.; Butera, J. A.; Chai, S.-Y.; McFarlane, G. R.; McKean, M. L.; Babiak, J. L.; Adelman, S. J.; Quinet, E. M. J. Med. Chem. 2004, 47, 681; (d) Yeh, W.-B.; Lin, M.-J.; Lee, M.-J.; Sun, C.-M. Mol. Divers. 2003, 7, 185; (e) Erve, J. C. L.; Amarnath, V.; Sills, R. C.; Morgan, D. L.; Valentine, W. M. Chem. Res. Toxicol. 1998, 11, 1128; (f) Marx, J. V.; Richert, D. A.; Westerfeld, W. W. J. Med. Chem. 1970, 13, 1179; (g) Johnson, T. B.; Hill, A. J.; Kelsey, E. B. J. Am. Chem. Soc. 1920, 42, 1711.

17. (a) Muccioli, G. G.; Martin, D.; Scriba, G. K. E.; Poppitz, W.; Poupaert, J. H.; Wouters, J.; Lambert, D. M. J. Med. Chem. 2005, 48, 2509; (b) Muccioli, G. G.; Poupaert, J. H.; Wouters, J.; Norberg, B.; Poppitz, W.; Scriba, G. K. E.; Lambert, D. M. Tetrahedron 2003, 59, 1301; (c) Muccioli, G. G.; Wouters, J.; Poupaert, J. H.; Norberg, B.; Poppitz, W.; Scriba, G. K. E.; Lambert, D. M. Org. Lett. 2003, 5, 3599.

18. Mahmoud, A. M.; Abdel-Rahman, A. E.; El-Naggar, G. M.; El-Sherief, H. A. Indian J. Chem. Sect. B 1984, 23B, 379.

19. Chain, E. B. The Chemical Structure of the Penicillins; Nobel Lecture, March 20, 1946. Available at http://nobelprize.org/nobel_prizes/medicine/laureates/1945/chain-lecture.pdf.

20. (a) Wang, X.-J.; Zhang, L.; Xu, Y. B.; Krishnamurthy, D.; Varsolona, R.; Nummy, L.; Shen, S.; Frutos, R. P.; Byrne, D.; Chung, J. C.; Farina, V.; Senanayake, C. H. Tetrahedron Lett. 2005, 46, 273; (b) Nefzi, A.; Giulianotti, M. A.; Houghten, R. A. Tetrahedron Lett. 2000, 41, 2283.

21. (a) Zhang, W.; Lu, Y. Org. Lett. 2003, 5, 2555; (b) Zhang, W. Tetrahedron, 2003, 59, 4475; (c) Gasch, C.; Salameh, B. A. B.; Pradera, M. A.; Fuentos, J. Tetrahedron Lett. 2001, 42, 8615; (d) Somsák, L.; Nagy, V.; Docsa, T.; Tóth, B.; Gergely, P. Tetrahedron: Asymmetr. 2000, 11, 405; (e) Floch, L.; Oremus, V.; Kovac, M. Molecules 1999, 4, 279; (f) Morin, J. M.; Ternansky, R. J.; Noreen, R.; Lind, P. T. U. S. Pat. 5,714,503, 1998; (g) Boyd, V. L.; Bozzini, M.; DeFranco, R. J. U. S. Pat. 5,665,603, 1997; (h) Morin, J. M.; Ternansky, R. J.; Noreen, R.; Lind, P. T. U. S. Pat. 5,658,907, 1997; (i) Sim, M. M.; Ganesan, A. J. Org. Chem. 1997, 62, 3230. 
22. (a) Park, K. H.; Kurth, M. J. J. Org. Chem. 1999, 64, 9297; (b) Karnbrock, W.; Deeg, M.; Gerhardt, J.; Rapp, W. Mol. Divers. 1998, 4, 165; (c) Matthews, J.; Rivero, R. A. J. Org. Chem. 1997, 62, 6090.

23. Kim, S. W.; Ahn, S. Y.; Koh, J. S.; Lee, J. H.; Ro, S.; Cho, H. Y. Tetrahedron Lett. 1997, 38, 4603.

24. Ganesan, A. Pure Appl. Chem. 2001, 73, 1033.

25. (a) Bailey, J. M.; Shively, J. E. Biochemistry 1990, 29, 3145; (b) Suzuki, T.; Song, K.-D.; Itagaki, Y.; Tuzimura, K. Org. Mass Spectrom. 1976, 11, 557; (c) Stark, G. R. Biochemistry 1968, 7, 1796; c) Turner, R. A.; Schmerzler, G. Biochim. Biophys. Acta 1954, 13, 553; (d) Fox, S. W.; Hurst, T. L.; Griffith, J. F.; Underwood, O. J. Am. Chem. Soc. 1955, 77, 3119.

26. (a) Baptist, V. H.; Bull, H. B. J. Am. Chem. Soc. 1953, 75, 1727; (b) Kuck, J. F. R.; Herda, J. J.; Kovac, W. E.; Karabinos, J. V. J. Am. Chem. Soc. 1951, 73, 5470.

27. Alfa Aesar Catalogue, 2006-2007.

28. Xia, Y. L.; Legge, G.; Jun, K.-Y.; Qi, Y. L.; Lee, H. J.; Gao, X. L. Mag. Reson. Chem. 2005, 43, 372.

Sample Availability: Samples of the compounds described in this manuscript are available from authors.

Supplementary Data: available as the file 11090739-suppl.pdf.

(C) 2006 by MDPI (http://www.mdpi.org). Reproduction is permitted for noncommercial purposes. 